\title{
Reproductive capacity of the eastern oyster Crassostrea virginica infected with the parasite Perkinsus marinus
}

\author{
Victor S. Kennedy ${ }^{1, *}$, Roger I. E. Newell ${ }^{1}$, George E. Krantz ${ }^{2}$, Sally Otto ${ }^{2}$ \\ ${ }^{1}$ University of Maryland System, Horn Point Environmental Laboratory, PO Box 775, Cambridge, Maryland 21613, USA \\ ${ }^{2}$ Maryland Department of Natural Resources, Cooperative Oxford Laboratory, 904 South Morris Street, Oxford, \\ Maryland 21654, USA
}

\begin{abstract}
We studied the influence of the protozoan parasite Perkinsus marinus (Mackin, Owen \& Collier) on reproduction in the eastern oyster Crassostrea virginica (Gmelin) from 2 sub-estuaries of central Chesapeake Bay, Maryland, in 1990 and 1991 One hypothesis was that increased levels of infection by $P$. marinus would result in smaller egg size and diminished lipid reserves within individual eggs. Our results did not reveal any consistent deleterious effects of $P$. marinus on these gametogenic characteristics, although some of our sample sizes were small and the average disease intensities were low. Our second hypothesis, that there would be a decline in reproductive output as a result of high levels of $P$. marinus infection, was supported for one estuary when those oysters were near their peak of reproductive condition (July). We found no evidence to support our third hypothesis that there would be a negative influence of infections during the 1990 reproductive season on subsequent reproductive output (summer 1991). Based on published evidence that $P$. marinus can inhibit oyster growth, we speculate that oysters infected at low intensities by $P$. marinus can divert energy from growth to reproduction. This differential energy partitioning allows infected oysters to produce fewer eggs than uninfected oysters but with no change in the amount of lipid reserves stored in each egg.
\end{abstract}

KEY WORDS: Oyster - Disease · Reproduction - Crassostrea virginica $\cdot$ Perkinsus marinus

\section{INTRODUCTION}

Infections by the protozoan parasite Perkinsus marinus (Mackin, Owen \& Collier), commonly called 'dermo', are responsible for high mortalities on beds of eastern oysters Crassostrea virginica (Gmelin) in the Gulf of Mexico and as far north as Delaware Bay on the U.S. Atlantic Coast. Severe $P$. marinus infections cause reduced growth (Andrews 1961, Paynter \& Burreson 1991) and ultimately the death of the host (Andrews 1988). However, little is known about the effects of the parasite on the oyster's physiology either before death, or when infections are sub-patent and do not cause mortality. Distributional survey data (Krantz 1991a, b) indicate that $P$. marinus has spread into regions of Chesapeake Bay

\footnotetext{
•E-mail: kennedy@hpel.umd.edu
}

that were once thought to have salinities too low to allow active infection (see Andrews 1988)

Oysters in Chesapeake Bay are also infected by the protozoan parasite Haplosporidium nelsoni (Haskin, Stauber \& Mackin), commonly called MSX (Haskin \& Andrews 1988). Feeding rates of oysters infected with H. nelsoni are significantly reduced (Newell 1985), resulting in a reduction in condition index (Newell 1985, Barber et al. 1988a). Infected oysters also have lower amounts of stored carbohydrate than is necessary to provide energy for normal gametogenic and vitellogenic activity (Barber et al. 1988b). This disruption of energy allocation in MSX-infected oysters results in significantly inhibited gametogenesis in spring (Ford et al. 1990) and a reduction in fecundity (Barber et al. 1988a).

In contrast to what is known about the effects of MSX, there is limited information available on the 
effects of Perkinsus marinus on reproduction by Crassostrea virginica. In Louisiana, Mackin (1953) examined oyster tissue histologically and found heavy infections to be associated with resorbed or destroyed gonadal tissue. In Texas, Choi et al. (1989) used a bioenergetic approach to propose that light infections of $P$. marinus have little or no effect on oyster reproduction. After our study (reported here) was complete, Choi et al. (1993) reported no statistical relationship between infection intensity by $P$. marinus and reproductive output (measured as the number of eggs in the gonad and the index of dry egg weight to dry body weight). Choi et al. (1994) did report, however, that intense infections retard the rate of gamete development during the fall but not during the spring spawning period in eastern oysters from the Gulf Coast.

We investigated the influence of various levels of parasitism by Perkinsus marinus on the reproductive capacity of female and male eastern oysters from central Chesapeake Bay. We focused on 2 oyster bars (Cason and Sandy Hill) that had different histories of infection by $P$. marinus (Krantz 1991a, b). Cason had first become infected in 1989, exhibiting a prevalence of $97 \%$ and a full epizootic. By contrast, Sandy Hill had $50 \%$ prevalence in 1989 and was only in the early enzootic stages of infection. In 1990, oysters on both bars had 97 to $100 \%$ prevalence, with high intensity infections. We proposed that $P$. marinus infections would reduce reproductive output, just as MSX does. We also sought to determine whether egg size and lipid quality and quantity in eggs was affected. These are critical issues for maintenance of oyster populations in nature, because even if $P$. marinus infections are not severe enough to kill adult oysters they may still impose sufficient stress to affect egg production and egg quality (in terms of lipid content), hence compromising larval survival and recruitment.

\section{MATERIALS AND METHODS}

Spawning and gamete collection. We monitored (monthly) the prevalence of disease on oyster bars beginning in autumn 1989 in the Little Choptank River (Cason bar: $38^{\circ} 32^{\prime} \mathrm{N}, 76^{\circ} 15^{\prime} \mathrm{W}$ ) and in the Choptank River (Sandy Hill bar; $38^{\circ} 36^{\prime} \mathrm{N}, 76^{\circ} 10^{\prime} \mathrm{W}$ ). Cason bar is slightly more saline than Sandy Hill bar; for example, in 1991 salinity ranged from 10 to $14 \mathrm{ppt}$ over Cason and from 8 to 13 ppt over Sandy Hill during the study. Infection by Haplosporidium nelsoni in oysters was determined by microscopic examination of stained histological sections (Howard \& Smith 1983). Infection by Perkinsus marinus was determined by the rectal thioglycollate method in which infection intensities are visually rated on an 8 -point scale from negative $=0$ and very light $=1$ to very heavy $=7$ (Ray 1966, Howard $\&$ Smith 1983). The numerical values refer to the logarithm $\left(10^{0}, 10^{1}, \ldots 10^{7}\right)$ of the number of infectious particles counted in a micoscopic field. We use the term 'disease stage' to refer to these values in the text.

In 1990, we dredged about 150 adult oysters (each sampling period) in late May, late June and early July from Sandy Hill bar and mid-June, early July and late July from Cason bar. These oysters were then held for up to a month at Horn Point Environmental Laboratory in running estuarine water $(7$ to $9 \mathrm{ppt}$ ) chilled to $20^{\circ} \mathrm{C}$. We provided no supplemental feeding with cultured algae. When reproductive development was judged to be maximal, based on visual inspection of eggs dissected from a number of females, we periodically removed oysters from the conditioning tanks and placed them into spawning tables in running river water heated to 28 to $30^{\circ} \mathrm{C}$. On a number of occasions, we added sperm killed by sonication, or eggs dissected from adults, to the water as a further stimulus to spawning. After spawning occurred, or if there was no response after 2 or 3 attempts over a number of days, we placed spawned and non-spawned oysters in a refrigerator and processed them shortly thereafter for presence of diseases. Shell heights were measured from the umbo to the growing edge of the shell.

The first successful spawning occurred on July 9 1990, when 47 female and 7 male Sandy Hill oysters were stimulated to spawn as a group. We isolated females immediately upon the start of spawning by removing them from the spawning table and placing them individually in glass bowls; we had sufficient bowls to hold 39 females. Males were placed together in a plastic tray to release sperm. We screened each female's eggs through $175 \mu \mathrm{m}$ and $125 \mu \mathrm{m}$ screens to remove debris, and placed the eggs that passed the screens into estuarine water on ice until they could be counted or prepared for lipid analysis, as described below.

On 2 additional spawning attempts in July 1990 , 6 Sandy Hill females and 10 males spawned and were treated as before, except that each female had been placed in individual bowls before being stimulated. (We did this because the eggs from the females on July 9 had been fertilized as a result of the mass spawning, precluding measurement of egg diameters because of morphological changes accompanying early cell division).

In spite of 7 attempts to stimulate Cason oysters to spawn in June and July 1990, only on one occasion (July 24) did 2 females and 1 male spawn in separate bowls. All spawned eggs were treated as above.

In 1991, we collected Sandy Hill oysters on May 29 and Cason oysters on June 3 . The oysters were held in 
the laboratory as in 1990 and spawning was attempted between June 12 and August 8 . Spawned eggs from 31 Sandy Hill oysters and 1 Cason oyster were treated as in 1990. Most oysters were spawned in separate containers, but mass spawning was attempted on a few occasions.

We used a Coulter Multisizer II to count the number of eggs spawned by all oysters and to determine egg diameter for 8 oysters in 1990 and 26 oysters in 1991 that were spawned in separate containers and hence were not fertilized.

Lipid analysis. Lipids were extracted from the eggs in basic accordance with the method of Bligh \& Dyer (1959). We filtered sufficient egg suspension onto Whatman GF/C glass fiber filters to give an average of about 560000 eggs per filter. Total lipid extracted from each filter was determined gravimetrically, from which we calculated total lipid per egg. An aliquot of the lipid extract was esterified according to the method of Morrison \& Smith (1964) and subjected to fatty acid methyl ester analysis (65 min) on a gas chromatograph equipped with a Supelco Wax 10, $60 \mathrm{~m}$ glass column (0.75 mm i.d.) with $1.0 \mu \mathrm{m}$ film thickness.

In 1990, quantification of fatty acids was done by use of an internal standard (C20:0 free fatty acid) which was added to the samples during the extraction procedure. Response correction factors were calculated from injections of known amounts of selected fatty acid methyl ester standards and the calculated values were used to normalize the flame ionization detector response. In 1991, quantification of fatty acid methyl ester was performed by use of a different internal standard (C23:0 free fatty acid) that was added to the samples during the extraction procedure. We attempted to obtain 3 samples of eggs from each female for total lipid analysis, but sometimes there were only enough eggs for 2 samples. These data were used to calculate mean values of total lipids and fatty acids for each female.

Reproductive condition. We estimated reproductive condition of female and male oysters histologically. Fifty adult oysters were collected at approximately monthly intervals from Cason bar from April through August in 1990 and 1991. We expanded the sampling in 1991 to include Sandy Hill bar as disease prevalence on the bar increased.

A section of the visceral mass of each oyster was removed from between the junction of the gills and palps and a point $5 \mathrm{~mm}$ towards the ventral margin. This tissue part, which is routinely used to assess the reproductive condition of oysters (Kennedy \& Krantz 1982, Morales-Alamo \& Mann 1989), was treated by histological techniques commonly used in fixation, sectioning, and staining (Howard \& Smith 1983).
A reproductive index of both female and male oysters combined was calculated by expressing the width of the germinal tissue of both genders as a percentage of the area of the somatic tissue enclosed by the gonad. (Wilson et al. 1990 found that infection by Perkinsus marinus was not related to gender.) We used a photographic enlarger to project the image of the histological section onto a Jandel Scientific digitizer tablet linked to a microcomputer. The relevant measurements were then digitized by the Sigma Scan software system (Jandel Scientific). The basis of this method is that the area of somatic tissue is conservative, but that as the oyster becomes more gravid and then spawns, the width of the germinal tissue surrounding the somatic tissue will first expand, then contract. This index is preferable to visual assessment of gonad stages (Kennedy \& Krantz 1982) because it not only provides information on the oyster's reproductive cycle but it is also a quantitative index of germinal production (Mori 1979, Perdue et al. 1981).

The optimum position for assessing the oyster's reproductive condition is the junction of the gills and labial palps (Morales-Alamo \& Mann 1989) because the gonad does not form a complete circle around the digestive gland at extreme dorsal and ventral positions of the visceral mass. Newell (unpubl.) calibrated the gonad-width measurement method against the gonad area method (Mori 1979, Perdue et al. 1981, Barber et al. 1988a) by using serial sections cut from along the entire length of the gonad of a gravid oyster and assessing reproductive development as described above. Both estimates gave comparable results for sections cut from the optimum position. However, the width method gave an accurate estimate of reproductive condition in sections for which the area measurement method significantly underestimated an individual's reproductive condition.

\section{RESULTS}

There was no evidence of the presence of Haplosporidium nelsoni in any oysters examined microscopically in this study. Thus evaluation of the data focused on the influence of Perkinsus marinus.

In 1990, 53 females from Sandy Hill and 2 from Cason released eggs. In 1991, 31 females from Sandy Hill and 1 from Cason spawned (we have no explanation for the difficulty in spawning oysters from Cason compared with those from Sandy Hill). The average of the disease stages of Perkinsus marinus for oysters that spawned did not differ significantly from the average for those that did not spawn (Table 1) [1990 Cason oysters: $t_{144}=0.693, \mathrm{p}>0.05 ; 1991$ Sandy Hill oysters: $\left.t_{[114]}=1.058, \mathrm{p}>0.05\right]$. 
Table 1 Crassostrea virginica. Comparison of average values of Perkinsus marinus disease stage for Sandy Hill and Cason oyster females that spawned or did not spawn when stimulated during various spawning attempts in 1990 and 1991. $n$ = number of oysters. Data for the mean \pm SE were calculated for all spawning or nonspawning oysters within a location and year

\begin{tabular}{|c|c|c|c|c|}
\hline \multirow{2}{*}{$\begin{array}{l}\text { Spawning } \\
\text { attermpt }\end{array}$} & \multicolumn{4}{|c|}{ Average stage of disease } \\
\hline & Spawning oysters & $\mathrm{n}$ & Nonspawning oysters & $\mathrm{n}$ \\
\hline \multicolumn{5}{|l|}{1990} \\
\hline \multicolumn{5}{|l|}{ Sandy Hill } \\
\hline Jul 9 & 0.2 & $33^{a}$ & 0.3 & 24 \\
\hline Jul 16 & 0.7 & 3 & - & 0 \\
\hline \multirow[t]{2}{*}{ Jul 17} & 0.3 & 3 & - & 0 \\
\hline & $\overline{0.3 \pm 0.44}$ & $\overline{39}$ & $\overline{0.3 \pm 0.17}$ & $\overline{24}$ \\
\hline \multicolumn{5}{|l|}{ Cason } \\
\hline Jul 24 & 3.5 & 2 & $2.8 \pm 0.33$ & 14 \\
\hline \multicolumn{5}{|l|}{1991} \\
\hline \multicolumn{5}{|l|}{ Sandy Hill } \\
\hline Jun 14 & 2.0 & 3 & 1.5 & 15 \\
\hline Jun 21 & 2.5 & 2 & 1.3 & 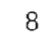 \\
\hline Jun 28 & 0.7 & 3 & 0.9 & \\
\hline Jul 12 & 1.5 & 4 & 2.4 & 25 \\
\hline Jul 19 & 1.3 & 9 & 1.0 & 20 \\
\hline \multirow[t]{2}{*}{ Aug 8} & 0.5 & $\underline{10}$ & 1.6 & $\underline{8}$ \\
\hline & $\overline{1.16 \pm 0.32}$ & $\overline{31}$ & $1.56 \pm 0.20$ & $\overline{85}$ \\
\hline \multicolumn{5}{|l|}{ Cason } \\
\hline Jun 21 & - & 0 & 2.4 & 10 \\
\hline Jun 28 & - & 0 & 3.6 & 8 \\
\hline \multirow[t]{2}{*}{ Jul 2} & $\underline{3}$ & $\underline{1}$ & 3.3 & 24 \\
\hline & $\overline{3}$ & $\overline{1}$ & $3.2 \pm 0.28$ & $\overline{42}$ \\
\hline
\end{tabular}

Data lost for 6 of the 39 females whose spawn was collected in individual bowls (see text)

larger than some from Sandy Hill oysters (Table 2). The largest eggs (48.1 $\mathrm{\mu m}$ ) in 1991 were spawned by an oyster in disease stage 2 . In summary, these 1990 and 1991 data do not reveal a consistent relationship between egg diameter and disease stage.

\section{Lipid analysis}

The average total lipid in the eggs spawned from oysters collected from Sandy Hill and uninfected with Perkinsus marinus was variable (Table 2), ranging from 4.04 to $4.26 \mathrm{ng} \mathrm{egg}^{-1}$ in 1990 and from 3.40 to $6.10 \mathrm{ng} \mathrm{egg}^{-1}$ in 1991. For disease stage 1 infections, values for lipid content of eggs ranged from 2.29 to $5.03 \mathrm{ng} \mathrm{egg}^{-1}$ in 1990 and from 2.58 to $4.16 \mathrm{ng} \mathrm{egg}^{-1}$ in 1991 . For disease stages 2 to 7 , total lipid content showed no decline with increasing stage level of disease in 1991 (Table 2). There was no statistical difference among average concentrations of lipids per egg among disease stages 0 and 1 in 1990 (Model II ANOVA, $F_{1,36}=0.38 \mathrm{~ns}$ ) and disease stages $0,1,2$, and 3 to 7 (combined) in 1991 (Model II ANOVA, $F_{3,27}=0.52 \mathrm{~ns}$ ).

Unfortunately, as only 3 Cason oysters spawned in both years and all were infected with Perkinsus marinus, it is not possible to determine if the total egg lipid content varied between populations on the 2 oyster bars (Table 2). In 1990 the lipid content of 1 Cason oyster ( $3.68 \mathrm{ng} \mathrm{egg}^{-1}$ ) fell within the range for Sandy Hill oysters; the value for the other

\section{Egg size}

In 1990, there was little variation in egg diameter among the 8 oysters from both locations whose eggs were measured before fertilization occurred (Table 2). There was no apparent relationship between the numerical stage of Perkinsus marinus infection and egg diameter in 1990, with the 2 Cason oysters having both the most severe infections and the largest $(49.3 \mu \mathrm{m})$ and smallest $(45.6 \mu \mathrm{m})$ mean egg diameters of the 8 adults. The slope of the regression equation relating egg size to disease stage for the 6 Sandy Hill oysters was not significantly different from zero (Model II Anova, $F_{1,4}=1.11 \mathrm{~ns}$ ).

In 1991, variation among egg diameters was higher and the measured sizes tended to be smaller than in 1990 (Table 2). Again, there was no relation between egg diameter and disease stage, with the regression equation for Sandy Hill oysters not significantly different from zero (Model II Anova, $F_{1,23}=1.09 \mathrm{~ns}$ ). The eggs from the Cason oyster, although small, were
(2.81 $\mathrm{ng} \mathrm{egg}^{-1}$ ) fell within the range of disease stage 1 oysters from Sandy Hill, but was lower than the range for uninfected oysters. In 1991, the lipid content of the Cason oyster was the second lowest measured that summer.

Concentrations of total lipid per egg and of fatty acid methyl esters increased with egg diameter for Sandy Hill oysters in 1990 (Figs. 1 \& 2). However, there was no discernible effect of infection in the Sandy Hill oysters on lipid composition, although the number of samples (6) was small. The lipid content of eggs from the 2 Cason oysters (disease stages 2 and 5) was lower than for oysters from Sandy Hill (Figs. 1 \& 2), even though one of the oysters produced the largest diameter eggs we measured, which thus would have been expected to contain more lipid.

In 1991, there was no significant relationship between egg diameter and total lipid per egg (Fig. 3) or fatty acid methyl esters per egg (Fig. 4) (a t-test revealed that none of the slopes of fitted regression lines differed significantly from zero, $p>0.05$ ). The 
Table 2. Crassostrea virginica. Relationship of Perkinsus marinus disease stage and mean ( $\pm 1 \mathrm{SE}$ ) values for shell height, total lipid content of eggs, and egg diameter for oysters from Sandy Hill and Cason oyster bars in July 1990 and June-August 1991 Number in parentheses is number of oysters measured (in the instances where only 1 oyster was measured, the single measurement is presented)

\begin{tabular}{|c|c|c|c|}
\hline $\begin{array}{l}\text { Disease } \\
\text { stage }\end{array}$ & $\begin{array}{c}\text { Mean } \\
\text { height }(\mathrm{cm})\end{array}$ & $\begin{array}{c}\text { Mean total } \\
\text { lipid (ng egg }{ }^{-1} \text { ) }\end{array}$ & $\begin{array}{c}\text { Mean } \\
\text { egg diameter }(\mu \mathrm{m})\end{array}$ \\
\hline \multicolumn{4}{|c|}{ July 1990} \\
\hline \multicolumn{4}{|c|}{ Sandy Hill } \\
\hline 0 & $9.5 \pm 0.22(30)$ & $4.26 \pm 0.17(29)$ & $47.3 \pm 0.49(4)$ \\
\hline 1 & $9.8 \pm 0.22$ & $4.04 \pm 0.30$ & $48.0(2)$ \\
\hline \multicolumn{4}{|l|}{ Cason } \\
\hline 2 & d & $2.81(1)$ & $45.6(1)$ \\
\hline 5 & a & $3.68(1)$ & $49.3(1)$ \\
\hline \multicolumn{4}{|c|}{ June-August 1991} \\
\hline \multicolumn{4}{|c|}{ Sandy Hill } \\
\hline 0 & $8.6 \pm 0.50(18)$ & $4.09 \pm 0.23(18)$ & $45.4 \pm 0.39(14)$ \\
\hline 1 & $9.1 \pm 1.41$ & $3.43 \pm 0.46$ & $43.3(2)$ \\
\hline 2 & $8.7 \pm 0.65$ & $3.97 \pm 0.24$ & $45.1 \pm 1.23$ \\
\hline 3 & $7.4(1)$ & $4.46(1)$ & $43.4(1)$ \\
\hline 4 & $8.3(2)$ & $4.25(2)$ & $43.4(2)$ \\
\hline 5 & $11.5(1)$ & $6.10(1)$ & $43.8(1)$ \\
\hline 7 & $9.4(1)$ & $3.40(1)$ & $46.0(1)$ \\
\hline \multicolumn{4}{|l|}{ Cason } \\
\hline 3 & $8.3(1)$ & $2.58(1)$ & $43.9(1)$ \\
\hline \multicolumn{4}{|c|}{ a Shell heights missing } \\
\hline
\end{tabular}

lower lipid and fatty acid concentrations than nearly all Sandy Hill oysters, no matter what their level of infection (Figs. $5 \& 6$ ).

\section{Reproductive condition}

Results of the histological evaluation of reproductive condition in 1990 indicated that, irrespective of disease stage, the reproductive index increased from April to May on Cason bar, declined slightly in June, and increased through early July to a maximum in late July followed by a sharp decline by the end of August (Fig. 7). In 1991, reproductive condition was generally similar on both bars from April through early July (Fig. 7). However, reproductive condition in late July was lower on Cason bar than on Sandy Hill. In late August, oysters from both bars were reproductively quiescent as indicated by index values of 1 or less.

We used least squares regression analysis followed by analysis of covariance (SAS GLM procedures; SAS 1988) to test our a priori hypothesis that there is an inverse relationship between reproductive condition and degree of Perkinsus marinus infection. For both locations there was a significant $(\mathrm{p}<0.05)$ inverse rela-

single oyster from Cason bar had lower concentrations of total lipids and fatty acids than nearly all Sandy Hill oysters (Figs. $3 \& 4$ ).

In 1991, there was no significant relationship between stage of Perkinsus marinus infection and total lipid or fatty acid composition at Sandy Hill (Figs. 5 \& 6) (again, none of the slopes of fitted regression lines differed significantly from zero, $p>0.05$ ). The single oyster from Cason bar was only moderately infected, and had

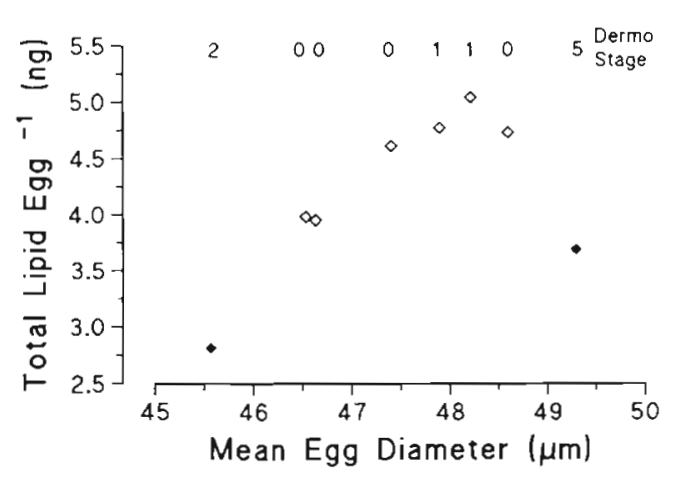

Fig. 1. Crassostrea virginica. Relation of total lipids per egg to mean egg diameter for oysters from Cason bar $(\bullet)$ and Sandy Hill bar $(\diamond)$ in 1990. Stage of dermo (Perkinsus maninus) disease is indicated for each oyster tionship only on the 2 times in July each year when oysters were collected from Cason bar (Fig. 7). On 1 occasion (Sandy Hill; April 29, 1991) there was an unexplained significant positive relationship.

We subsequently used both analysis of variance and analysis of covariance (GLM; SAS 1988) to test our a priori hypothesis that reproductive condition differed between years and oyster bars because of differences in the years when severe infections were first observed

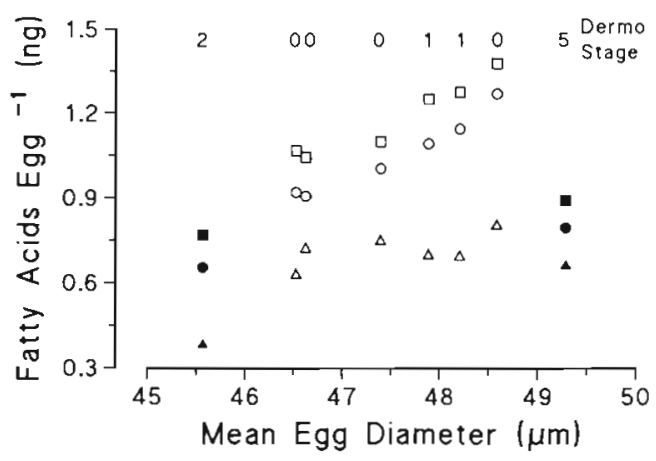

Fig. 2. Crassostrea virginica. Relation of saturated $(\boldsymbol{\Delta}, \Delta)$, unsaturated $(\boldsymbol{\sigma}, \mathbf{0})$, and $\omega-3$ fatty acids $(\bullet, 0)$ to mean egg diameter for oysters from Cason bar (closed symbols) and Sandy Hill bar (open symbols) in 1990. Stage of dermo (Perkinsus marinus) disease is indicated for each oyster 


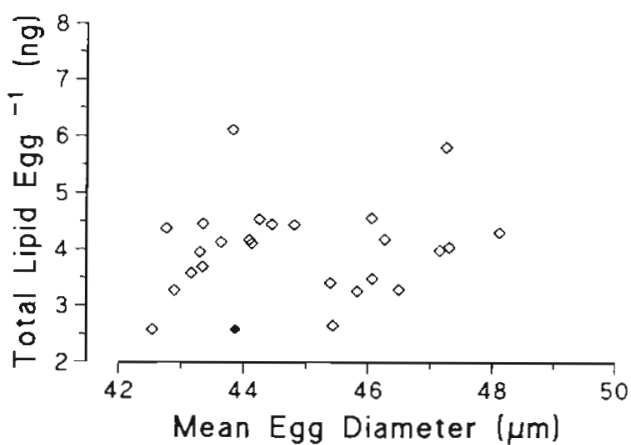

Fig. 3. Crassostrea virginica. Relation of total lipids per egg to mean egg diameter for oysters from Cason bar ( ) and Sandy Hill bar $(\diamond)$ in 1991

on these bars (see 'Introduction'). For the 4 occasions in July 1990 and 1991 when there were significant regressions for Cason oysters, analyses of covariance revealed that, contrary to our hypothesis, there were no significant yearly differences between slopes and intercepts for early July (Fig. 7). For late July, the intercept was significantly lower in 1991. Although this was in agreement with our hypothesis, it is likely that the reduced reproductive index for Cason in 1991 (Fig. 7) was due to the population being spawned out.
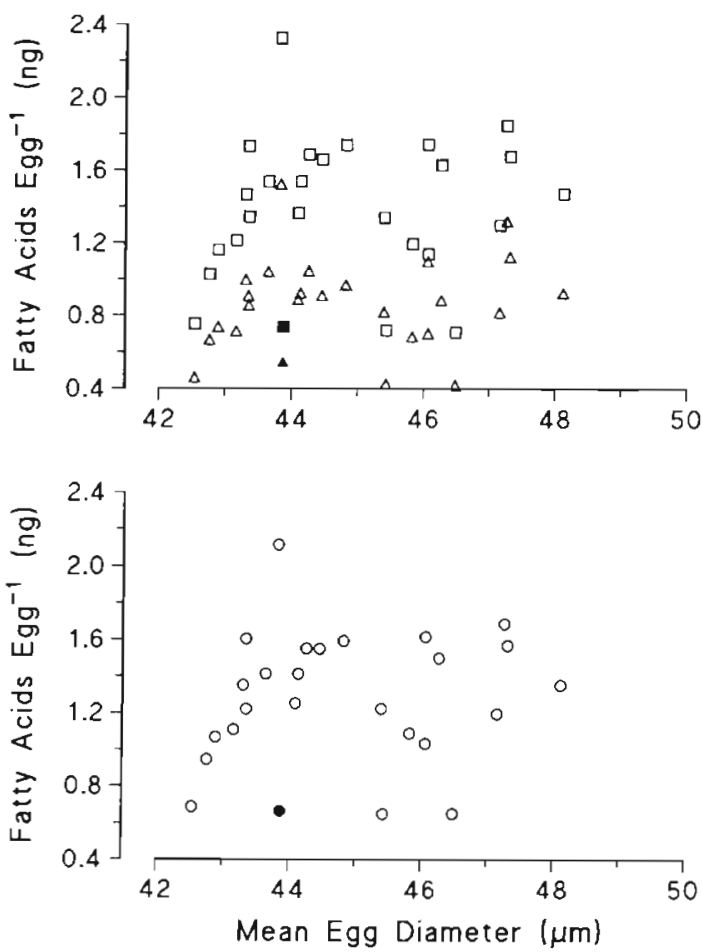

Fig. 4. Crassostrea virginica. Relation of (upper panel) saturated $(\Delta, \Delta)$ and unsaturated $(\boldsymbol{\square}, 0)$ fatty acids and (lower panel) $\omega$-3 fatty acids to mean egg diameter for oysters from Sandy Hill bar (open symbols) and Cason bar (closed symbols) in 1991

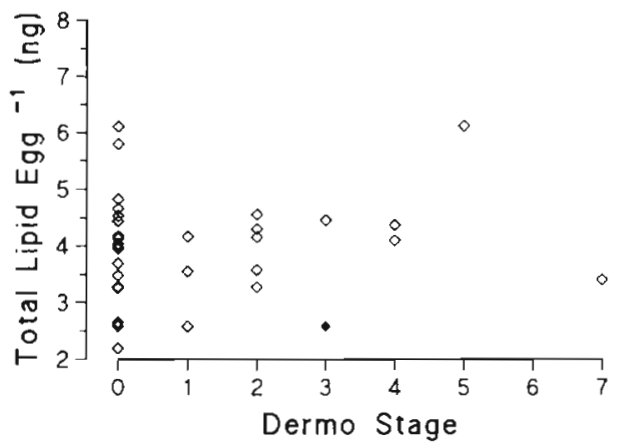

Fig. 5. Crassostrea virginica. Relation of total lipids per egg to stage of dermo (Perkinsus marinus) disease for oysters from Sandy Hill bar $(\diamond)$ and Cason bar $(\bullet)$ in 1991

Analyses of variance (with month, year, and location as factors) revealed 4 instances in which reproductive condition was significantly different between years or bars $(p<0.05)$. Oysters from Cason bar on July 30, 1990, had a significantly higher reproductive condition than those on July 30, 1991. Contrarily, for Cason bar in early April and early June, reproductive condition was higher in 1991 than in 1990 (Fig. 7), in opposition
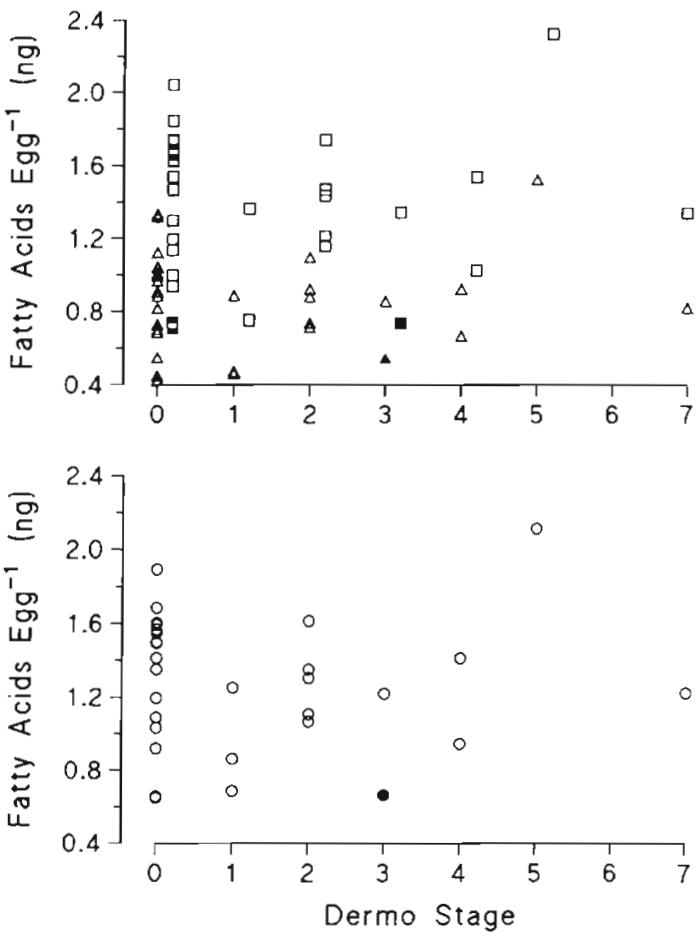

Fig. 6. Crassostrea virginica. Relation of (upper panel) saturated $(\boldsymbol{\Delta}, \Delta)$ and unsaturated $(\boldsymbol{\square}, \mathbf{\square})$ fatty acids and (lower panel) $\omega-3$ fatty acids to stage of dermo (Perkinsus marinus) disease for oysters from Sandy Hill bar (open symbols) and Cason bar (closed symbols) in 1991 For clanty, symbols for data on saturated and unsaturated fatty acids are slightly offset in the upper panel 
Fig. 7. Crassostrea virginica. Reproductive index [(average gonad width $\div$ body area) $x$ 100 ] versus stage of dermo (Perkinsus marinus) disease in female and male oysters collected at different times from Cason oyster bar in 1990 and 1991 and from Sandy Hill oyster bar in 1991 and examined histologically. On the figure, each vertical bar represents the mean ( $\pm \mathrm{SE}$ ) reproductive index for the number of oysters annotated above that bar. Data for the 5 regressions are as follows (presented in the order of slope, intercept, probability value for F-test, and $\mathrm{R}^{2}$ ). Cason 1990, July 11: -0.16 , $1.99,0.02,0.50$; Cason 1990, July 30: -0.27 , $2.38,0.03,0.47$; Cason 1991, July 1: -0.23 $1.92,0.02,0.29$; Cason 1991, July 30: -0.08 , $0.76,0.04,0.25$; Sandy Hill 1991, April 29: $0.01,0.56,0.03,0.24$
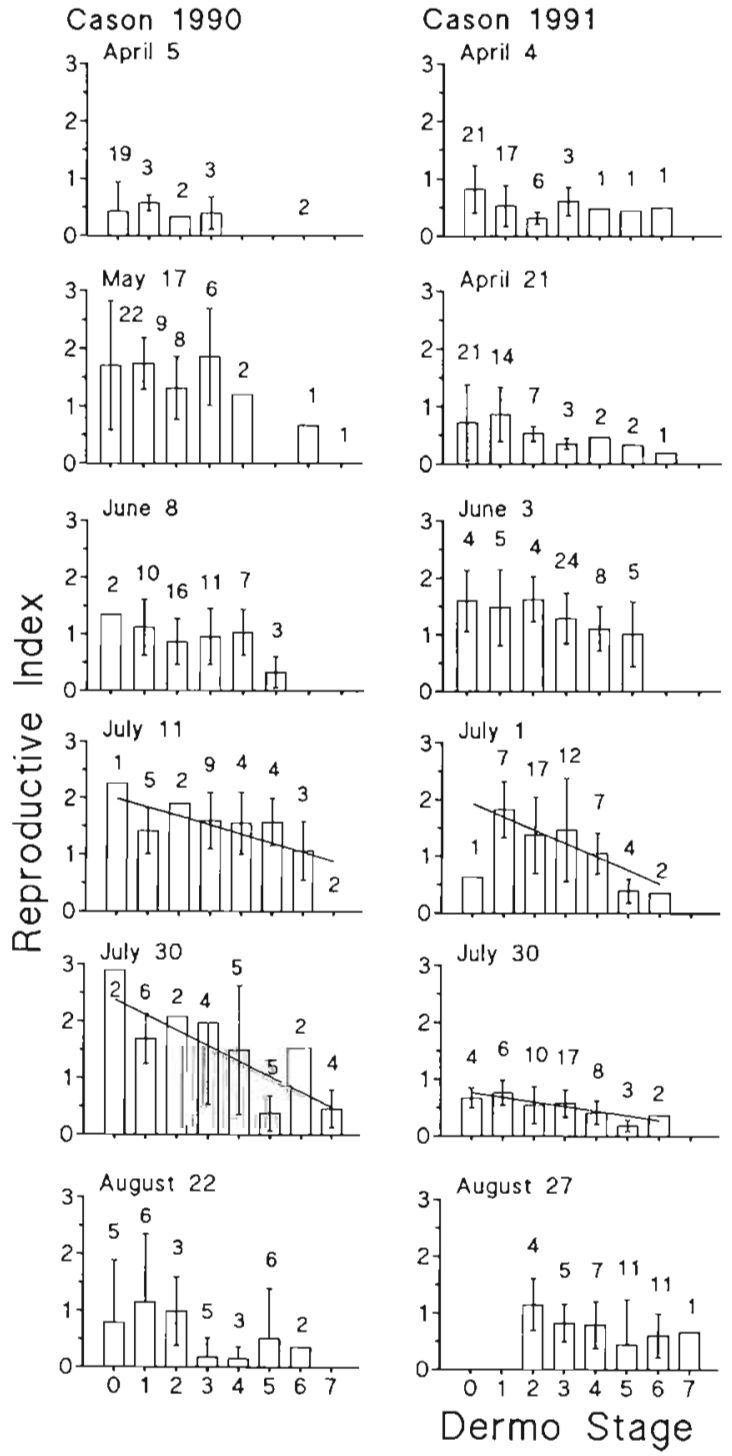

Sandy Hill 1991

April 8
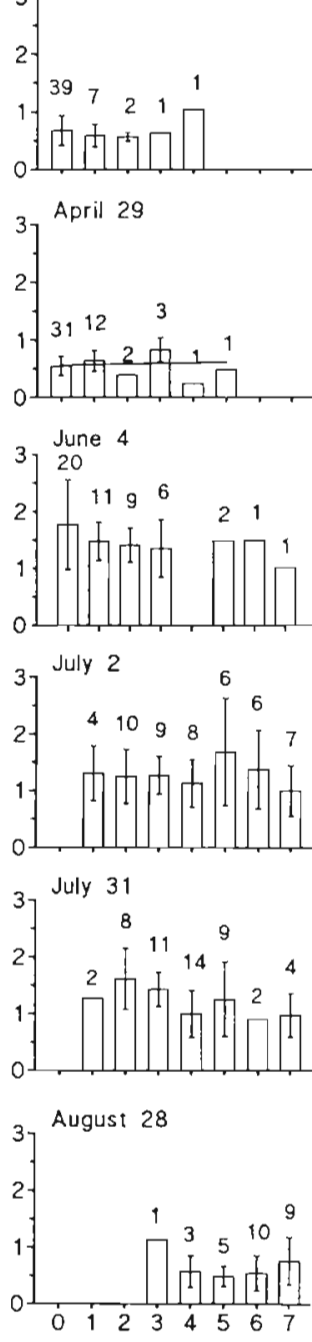

to our hypothesis that the extended duration and intensity of infection by Perkinsus marinus at this location would inhibit reproduction. For comparisons between Cason and Sandy Hill, in June and late July, 1991 (Fig. 7) reproductive condition on Sandy Hill was significantly higher than on Cason. Although this result seems to support our hypothesis, the support is weak because the mean value of the reproductive index for Cason in June was $1.3 \pm 0.52(\mathrm{SD})(\mathrm{n}=50)$ and for Sandy Hill was $1.6 \pm 0.61(n=50)$, and the $R^{2}$ value describing variation in reproductive index between the 2 sites was only 0.05 . As before, we believe the low reproductive condition in the Cason population in late July 1991 was due to spawning. Thus, we found no evidence that low-intensity infections in prior reproductive seasons reduced fecundity in subsequent reproductive seasons.

\section{DISCUSSION}

Perkinsus marinus exhibits an annual cycle of infection intensity related primarily to water temperature, with the highest parasite body burdens generally being found when water temperatures exceed $20^{\circ} \mathrm{C}$ (Andrews 1988). This is in direct contrast to the other major eastern oyster parasite, Haplosporidium nelsoni, in which infections are more intense during the spring and may actually go into remission when water temperature exceeds about $20^{\circ} \mathrm{C}$ (Haskin \& Andrews 1988). Parasitic infections, by definition, impose an energy drain on their host, and because infection intensities of $P$. marinus are highest in the summer, it is plausible that the parasitic stress would interfere with glycogen storage. Such stress may have long-term implications for the survival of oyster populations: in addition to providing 
energy for basal metabolism during winter quiescence, glycogen stored during summer and fall provides nutriments for gametogenesis during the late winter and early spring (reviewed by Thompson et al. 1995).

The oyster populations at Sandy Hill and Cason that we sampled in our study were experiencing epizootic infection of Perkinsus marinus, with Cason having reached epizootic conditions a year earlier than Sandy Hill (Krantz 1991a, b). Previous work by Paynter \& Burreson (1991) has shown that, at salinities (12 to $15 \mathrm{ppt}$ ) similar to those at Sandy Hill and Cason bars during the spawning season, shell growth in oysters with even very light infections of $P$. marinus (weighted prevalence $<0.6$ ) became severely inhibited during the summer. Paynter \& Burreson (1991) also reported that the condition index (an estimate of tissue and sequestered nutrient reserves) of infected oysters declined from summer through fall. In contrast, uninfected oysters showed an increase in condition index associated with the normal increase in stored carbohydrate that occurs during this period (Thompson et al. 1995).

Reproduction in bivalves that have been stressed energetically by high temperatures or starvation is affected in different ways depending upon exactly at what time in the reproductive cycle the stress is imposed (reviewed by Gabbott 1983). If the stress occurs early in the reproductive cycle, then the blue mussel Mytilus edulis (Bayne et al. 1978) and the European flat oyster Ostrea edulis (Helm et al. 1973) respond by producing fewer eggs, although those produced have a normal size and lipid composition and hatch to produce viable larvae. In contrast, when the females are stressed after the onset of oogenesis and the initial formation of the eggs, then vitellogenesis is affected and each egg is provided with a smaller yolk, significantly reducing larval viability.

Thus, we hypothesized that oysters infected by Perkinsus marinus may be stressed such that egg size and the amount or types of lipid stored in each egg may be adversely affected. Unfortunately, the data we obtained in 1990 on egg size and lipid content and composition of the eggs are difficult to interpret in terms of disease stage because of high variability and a lack of heavily infected oysters. However, it appears that biochemical composition and egg size were not adversely influenced by low intensity $P$. marinus infections, a result strongly supported by the more comprehensive data collected in $1991^{1}$. This

\footnotetext{
${ }^{1}$ It is of interest to note that the average egg lipid content we recorded for uninfected oysters and those exhibiting stage 1 infections was actually higher (ranging from 3.43 to $4.26 \mathrm{ng}$ $\mathrm{egg}^{-1}$; Table 2) than the value of $2.5 \mathrm{ng} \mathrm{egg}^{-1}$ measured by Lee \& Heffernan (1991) for oysters from Georgia, USA. Ignoring possible technical differences in the efficiency of lipid extraction, this suggests that oysters from Chesapeake Bay have a higher lipid content in their eggs than oysters from Georgia
}

result is similar to the findings by Choi et al. (1993) that there was no statistically significant relation between level of infection by $P$. marinus in Texas oysters and either number of eggs in the gonad or percent weight of eggs as a function of individual dry body weight.

We derived information on the possible effect of high infection levels of Perkinsus marinus on the oysters' reproductive output from monthly histological measures of reproductive condition, which estimate potential fecundity in vivo at the time of collection of the adults (Mori 1979, Barber et al. 1988a). From our regression analysis it is apparent that, when oysters from Cason bar were at the peak of their reproductive cycle in July, reproductive output was significantly reduced, and even completely inhibited in 1990 in oysters with high $P$. marinus infections (Fig. 7). Similarly, Mackin (1953) also reported that oysters in Louisiana with heavy $P$. marinus infections failed to initiate gonad development. Contrarily, in Sandy Hill oysters we observed no clear decrease in the index with disease stage (Fig. 7).

We used the same data on reproductive condition to test the hypothesis that oysters stressed by Perkinsus marinus infections in the summer of the previous year (1990) had reduced fecundity in the subsequent reproductive season (1991). This hypothesis was not supported by results from Cason bar as reproductive condition was not consistently lower in 1991 compared with 1990. Similarly, in 1991 reproductive condition of oysters from Sandy Hill was not consistently higher than for Cason oysters despite epizootic conditions having prevailed for a year longer at Cason than at Sandy Hill. Thus, we conclude that there was no effect of the low infection intensities that we observed during the previous summer either on the gonadal index or abundance of eggs available to be spawned during the subsequent year

We now hypothesize that stress resulting from the low-intensity infections by Perkinsus marinus in oysters at our 2 study sites occurred sufficiently early in the reproductive cycle to allow the oysters to compensate by producing fewer eggs, but with no reduction in lipid content or egg size. This parallels findings on effects of the MSX parasite Haplosporidium nelsoni on reproduction in eastern oysters. Barber et al. (1988a) determined that eastern oysters with epithelial MSX infections had a condition index that was $13 \%$ lower and fecundity $31 \%$ lower than uninfected oysters. In oysters with systemic MSX infections, condition index was $31 \%$ lower and fecundity $81 \%$ lower than uninfected oysters. Reduction in fecundity was manifest primarily as a reduction in the number of eggs produced and not as a reduction in egg size. These observations suggest that because the stress induced by the MSX parasites was im- 
posed before the initiation of gametogenesis, the oysters could compensate by producing fewer eggs, but eggs that would still produce viable larvae. Ford \& Figueras (1988) and Ford et al. (1990) also reported that gametogenesis was inhibited in direct proportion to MSX infection intensity during the spring period of maximum intensity of MSX infection. However, they found that when high water temperatures during the summer reduced the virulence of the MSX parasite, many previously MSX-infected oysters subsequently developed mature gametes that were spawned normally.

In summary, we now postulate that Crassostrea virginica can compensate for low levels of Perkinsus marinus infection stress by 'protecting' gametogenesis and spawning by shunting energy from growth (Paynter \& Burreson 1991) to reproduction. This agrees with Wilson et al. $(1988,1990)$ who reported no consistent adverse effects of low $P$. marinus infections on reproduction (measured using a simple visual assessment of gonad condition) and condition index in oysters from the Gulf Coast. When oysters are more intensely infected, such as we observed in July at Cason bar, their reproductive capacity is severely reduced. This deleterious effect perhaps results from high parasite body-burdens imposing an acute drain on the energy assimilated by eastern oysters (Choi et al. 1989) and this reduces the ability of the oyster to 'protect' reproduction by diverting energy from growth, in contrast with the situation in lightly infected oysters.

Acknowledgements. We gratefully acknowledge the assistance of Donna Plutschak with histological analyses; Meg Maddox, Rachel Clark, and Beth Ebersole for assistance in spawning oysters and determining reproduction indices; Laurie van Heukelem for lipid analyses; and Christine Newell and Steve McIninch for statistical analyses and preparation of figures. We thank 3 anonymous reviewers for constructive comments on earlier drafts. Financial support was provided by Maryland's Department of Natural Resources. UMCEES Contribution Number 2649 of the University of Maryland System Center for Environmental and Estuarine Studies.

\section{LITERATURE CITED}

Andrews JD (1961) Measurement of shell growth in oysters by weighing in water. Proc natl Shellfish Ass 52:1-11

Andrews JD (1988) Epizootiology of the disease caused by the oyster pathogen Perkinsus marinus and its effects on the oyster industry. Am Fish Soc Spec Publ 18:47-63

Barber BJ, Ford SE, Haskin HH (1988a) Effects of the parasite MSX (Haplosporidium nelsoni) on oyster (Crassostrea virginica) energy metabolism. I. Condition index and relative fecundity. J Shellfish Res 7:25-31

Barber BJ, Ford SE, Haskin HH (1988b) Effects of the parasite MSX (Haplosporidium nelsoni) on oyster (Crassostrea vir- ginica) energy metabolism. Ir. Tissue biochemical composition Comp Biochem Physiol 91A:603-608

Bayne BL, Holland DL, Moore MN, Lowe DM, Widdows J (1978) Further studies on the effects of stress in the adult on the eggs of Mytilus edulis. J mar biol Ass UK 58:825-841

Bligh EG, Dyer WJ (1959) A rapid method of total lipid extraction and purification. Can J Biochem Physiol 37:911-917

Choi KS, Lewis DH, Powell EN, Ray SM (1993) Quantitative measurement of reproductive output in the American oyster, Crassostrea virginica (Gmelin), using an enzymelinked immunosorbent assay (ELISA). Aquacult Fish Mgmt 24:299-322

Choi KS, Powell EN, Lewis DH, Ray SM (1994) Instantaneous reproductive effort in female American oysters, Crassostrea virginica, measured by a new immunoprecipitation assay. Biol Bull 186:41-61

Choi KS, Wilson EA, Lewis DH, Powell EN, Ray SM (1989) The energetic cost of Perkinsus marinus parasitism in oysters: quantification of the thioglycollate method. J Shellfish Res 8:125-131

Ford SE, Figueras AJ (1988) Effects of sublethal infection by the parasite Haplosporidium nelsoni (MSX) on gametogenesis, spawning, and sex ratios of oysters in Delaware Bay, USA. Dis aquat Org 4:121-133

Ford SE, Figueras AJ, Haskin HH (1990) Influence of selective breeding, geographic origin, and disease on gametogenesis and sex ratios of oysters, Crassostrea virginica, exposed to the parasite Haplosporidium nelsoni (MSX). Aquaculture 88:285-301

Gabbott PA (1983) Developmental and seasonal metabolic activities in marine mollusks. In: Hochachka PW (ed) The Mollusca, Vol 2. Academic Press, New York, p 165-217

Haskin $\mathrm{HH}$, Andrews JD (1988) Uncertainties and speculations about the life cycle of the eastern oyster pathogen Haplosporidium nelsoni (MSX). Am Fish Soc Spec Publ $18: 5-22$

Helm HH, Holland DL, Stephenson RR (1973) The effects of supplementary algal feeding of a hatchery breeding stock of Ostrea edulis L. on larval vigour. J mar biol Ass UK 53: 673-684

Howard DW, Smith CS (1983) Histological techniques for marine bivalve molluscs. NOAA Tech Memo NMFSF/NEC 25. Northeast Fisheries Center, Woods Hole, USA

Kennedy VS, Krantz LB (1982) Comparative gametogenic and spawning patterns of the oyster Crassostrea virginica (Gmelin) in central Chesapeake Bay. J Shellfish Res 2: $133-140$

Krantz GE (1991a) Maryland oyster population status report: 1989 fall survey. CBRM-OX-90-01. Maryland Department of Natural Resources, Annapolis

Krantz GE (1991b) Maryland oyster population status report: 1990 fall survey. CBRM-OX-91-01. Maryland Department of Natural Resources, Annapolis

Lee RG, Heffernan PB (1991) Lipids and proteins in eggs of eastern oysters (Crassostrea virginica (Gmelin)) and northern quahogs (Mercenaria mercenaria) (Linnaeus, 1758)). J Shellfish Res 10:203-206

Mackin JG (1953) Incidence of infection of oysters by Dermocystidium in the Barataria area of Louisiana. Convention addresses, Natl Shellfish Ass 1951:22-35

Morales-Alamo R, Mann R (1989) Anatomical features in histological sections of Crassostrea virginica (Gmelin) as an aid in measurements of gonad area for reproductive assessment. J Shellfish Res 8:71-82

Mori K (1979) Effects of artificial eutrophication on the metabolism of the Japanese oyster, Crassostrea gigas. Mar Biol 53:361-369 
Morrison WR, Smith LM (1964) Preparation of fatty acid methyl esters and dimethylacetals from lipids with boronfluoride-methanol. J Lipid Res 5:600-608

Newell RIE (1985) Physiological effects of the MSX parasite Haplosporidium nelsoni (Haskin, Stauber and Mackin) on the American oyster Crassostrea virginica (Gmelin). J Shellfish Res 5:91-95

Paynter KT Jr, Burreson EM (1991) Effects of Perkinsus marinus infection in the eastern oyster, Crassostrea virginica: Il. Disease development and impact on growth rate in different salinities. J Shellfish Res 10:425 - 431

Perdue JA, Beattie JH, Chew KK (1981) Some relationships between gametogenic cycle and summer mortality phenomenon in the Pacific oyster (Crassostrea gigas) in Washington state. J Shellfish Res 1:9-16

Ray SM (1966) A review of the culture method for detecting Dermocystidium marinum with suggested modifications

Responsible Subject Editor: A. K. Sparks, Seattle, Washington, USA and precautions. Proc natl Shellfish Ass 54:55-69

SAS Inc (1988) SAS/STAT user's guide release 6.03 edition. Statistical Analysis Institute, Inc., Cary, NC

Thompson RJ, Newell RIE, Kennedy VS, Mann R (1995) Reproduction and larval development. In. Eble A, Kennedy VS, Newell RIE (eds) The Eastern Oyster, Crassostrea virginica. Maryland Sea Grant Publication, College Park (in press)

Wilson EA, Powell EN, Ray SM (1988) The effect of the ectoparasitic Pyramidellid snail Boonea impressa on the growth and health of oysters, Crassostrea virginica, under field conditions. US Fish and Wildl Serv Fish Bull 86: 553-566

Wilson EA, Powell EN, Craig MA, Wade TL, Brooks JM (1990) The distribution of Perkinsus marinus in Gulf coast oysters: its relationship with temperature, reproduction, and pollutant body burden. Int Rev ges Hydrobiol 75:533-550

Manuscript first received: September 24, 1994

Revised version accepted: April 17, 1995 